\title{
Effect of different supplementary cementitious materials and superplasticizers on rheological behavior of eco-friendly mortars
}

Salim SAFIDDINE Associate Professor at the Department of Civil Engineering, University of Medea, Algeria. His research interests include rheology and durability of eco-friendly concrete.

Hamza SOUALHI Assistant Professor at the Department of Civil Engineering, University of Laghouat, Algeria. His research interests include rheology, tribology and durability of concrete.

SALIM SAFIDDINE - Materials and Environmental Laboratory (LME), University of Yahia Fares, Algeria - safiddine.salim@univ-medea.dz

Hamza SOUALHI - Civil Engineering Research Laboratory (LRGC), University of Amar Telidji, Algeria - h.soualhi@lagh-univ.dz

BENCHAA BENABED - Civil Engineering Research Laboratory (LRGC), University of Amar Telidji, Algeria - b.benchaa@lagh-univ.dz

Akram SaLah Eddine BELAIDI - Civil Engineering Research Laboratory (LRGC), University of Amar Telidji, Algeria • s.belaidi@lagh-univ.dz

EL-HADJ KADRI - Laboratory L2MGC, University of Cergy-Pontoise, F9500, France - el-hadj.kadri@u-cergy.fr Érkezett: 2021. 05. 03. - Received: 03. 05. 2021. - https://doi.org/10.14382/epitoanyag-jsbcm.2021.18

\section{Abstract}

The drive towards using eco-friendly binders with increasing proportion of supplementary cementitious materials (SCMs) will lead to the development of more complex mixtures. However, the availability of fly ash (FA) would not cover future needs due to restrictions on the combustion of coal in power plants. Accordingly, the addition of limestone filler (LF) has an inherent advantage throughout the world of its availability in large deposits. The first main aim of this study was to determine the effect of high-volume LF used as Portland cement replacement with up to 60\% on the rheological properties of cement mortar compared to the FA and the slag (BFS). Unlike FA and BFS, an increase in LF replacement reduced the rheological properties of the mortar. The relationship obtained between relative solid concentration and rheological properties of mortar with different SCMs was reasonable. The second aim of this study was to determine the rheological behavior of the mortar with different superplasticizer (SP) admixtures. Three SP types were utilized, ether-polycarboxylic modified (SP1), phosphonate modified (SP2) and new generation of polycarboxylate (SP3), with various dosages. The results show that, SP2 reduced the rheological properties better than SP1 and SP3 with dosages of less than 1\%.

Keywords: eco-friendly mortars, rheological behavior, limestone filler, fly ash, slag, superplasticizer Kulcsszavak: környezetbarát habarcsok, reológiai viselkedés, mészkô töltôanyag, pernye, salak, folyósító

\section{Introduction}

Just after the power sector, the cement industry is one of the biggest contributors to greenhouse gases emissions and anthropogenic carbon dioxide in the world [1]. One of the most effective ways to minimize environmental damage associated with cement production is to increase the wider exploit of supplementary cementitious materials (SCMs) in cement composition. In some countries, the amount of fly ash (FA) is expected to be significantly affected in the future due to recent limits on coal combustion. As a result, there is an urgent need for the development of new SCMs, that are comparable or superior to FA and finely blast furnace slag (BFS) [2-4]. Accordingly, the use of limestone filler (LF) has a benefit of its availability in large quantity. Recent studies [5-7] show that it is possible to replace up to $50 \%$ by mass of cement with LF without reduction or with a slight decrease in mechanical strength. According to John et al. [6], this can be achieved if the effect of dilution is offset by a decrease in the amount of water used. Nevertheless, this is not a simple task as the rheological behavior of the mixture becomes more and more difficult to control with a low water-binder (W/B) ratio.
Many authors have investigated the use of SCMs for the production of low-impact environmental cement-based materials (grout, mortar or concrete). They have studied their effects on rheology, mechanical properties, durability, thermal conductivity and microstructure analysis of cement suspensions [8-30] as a result of nonlinear behaviour of concrete carbonation and uncertainties of environmental factors affecting the progress of carbonation. In reality, the performance of a developed predictive model lies on its ability to accurately generalise (simulate. The fact that equivalent performance can be reached, combined with a significantly enhanced sustainability and in some cases improved long-term durability, is driving the development of Portland cement-SCM blends towards an increase in substitution levels [2]. Likewise, the use of SCMs with different morphology and grain-size distribution can improve rheological properties and packing of solid particles [31]. This improvement in workability is most frequently associated with the less chemical activity and the smooth surface of SCMs grains compared to ordinary Portland cement (OPC). The most commonly used model in the rheology of cement suspensions is that of Bingham [32-34]elasticity and plasticity and with the \nappearance of new materials and the complex behaviour of concretelnpumpability, since the field of civil engineering is interested in thelnstudy of concrete flow. This work will examine how the use of catodiquelnray tube (CRT. 
A low yield stress and a moderate viscosity can be achieved by increasing the paste volume, to replace some part of the OPC with one or more SCMs, for a given W/B ratio [29]. The increased paste volume due to the difference in specific density of SCMs (less than $2.5 \mathrm{~g} / \mathrm{cm}^{3}$ ) and that of cement $\left(3.0-3.2 \mathrm{~g} / \mathrm{cm}^{3}\right)$ [35]. However, the evolution of rheological properties as a function of the partial substitution of cement by SCMs, in the literature, seems to be contradictory in some cases. This is due to the use of SCMs with different physical properties, chemical compositions, activity and filling effect [35-39]consistency, flowability, and predict stability, pumpability, shootability, pressure of formwork, multi-layer casting. This paper presents a critical review on the rheological properties of fresh concrete in recent publications. The applicable rheological models for the flow of concrete are revealed. The effects of constituents of fresh concrete, including cement, supplementary cementitious materials (fly ash, ground blast furnace slag, and silica fume. Furthermore, even if the addition is considered chemically inert, it can have major physical effects like the effects of improved surface area and particle packing [40] heat evolution, microstructure, and setting time. The properties of hardened mortar and concrete made with limestone portland cement are examined and compared to those made with non-limestone portland cements-including compressive and flexural strength, volume stability, durability (permeability, carbonation, freeze/thaw resistance, sulfate and chloride resistance, and alkali-silica reaction. On the other hand, it is important to know how different types of superplasticizer (SP) affect the rheological properties of cement-based materials. Since the nature of admixture used plays an important role in the rheology. It is usually reported that, the dispersion of cement particles, caused by SP, due to the electrostatic repulsion associated with zeta potential measurements. However, in reality this is not necessarily the case, it would seem that, at least for the acrylic polymer-based admixtures, the polymer adsorption itself is responsible for dispersing large agglomerates of cement particles into smaller ones resulting in a remarkable increase in the fluidity of cement mixes. It may be related more to a steric hindrance effect, i.e. repulsive particle-particle interactions [41,42].

For this purpose, the current study focuses on the rheological behavior of cement mortar containing various amounts of FA, LF and BFS as a partial replacement of cement. Thereafter, the effect of LF and tow SCMs used on laboratory tested rheological properties of cement mortar is compared. The aim of this study is also to compare the effects of the use of different types of SP admixtures (polymer and organic admixtures based). In view of the above, the rheological behavior of cement mortars with different content of LF, FA and BFS $(0,10,20,30,40,50$ and $60 \%)$ is studied. As well as with different dosages $(0,0.2,0.4$, 0.6 and $0.8 \%$ ) of three types of SP admixture.

\section{Experimental program}

\subsection{Materials}

All mortar mixtures were prepared using an OPC (CEM I 52.5). The SCMs used are fly ash (FA), finely blast furnace slag (BFS), and whitened limestone filler produced by direct grinding of limestone (LF). Table 1 presents the chemical composition and physical properties of the cement and mineral additions used. The particles size distribution of these materials, which was obtained using a laser scattering technique, is given in Fig. 1. From the curves, the particles size distribution of LF is large compared to that of cement, FA and BFS, which is small. Fine aggregate with a maximum size of $4 \mathrm{~mm}$ was used, with specific gravity of 2.5 according to Standard EN 1097-6 [43], and fineness modulus is 1.88 . Three types of superplasticizer (SP) were used in this study (Table 2). The first one is high water reducer (SP1) based on ether-polycarboxylic modified, with a specific gravity of 1.05 , a solid content of $20 \%$, and a $\mathrm{pH}$ of 7.0. The second one is based on phosphonate modified (SP2). It has a specific gravity, a solid content, and $\mathrm{pH}$ of 1.06 , $30 \%$, and 4 , respectively. The third one is high water reducer (SP3) from new generation of polycarboxylate with a specific gravity of 1.07, a solid content of $30 \%$, and $\mathrm{pH}$ of 6.5 .

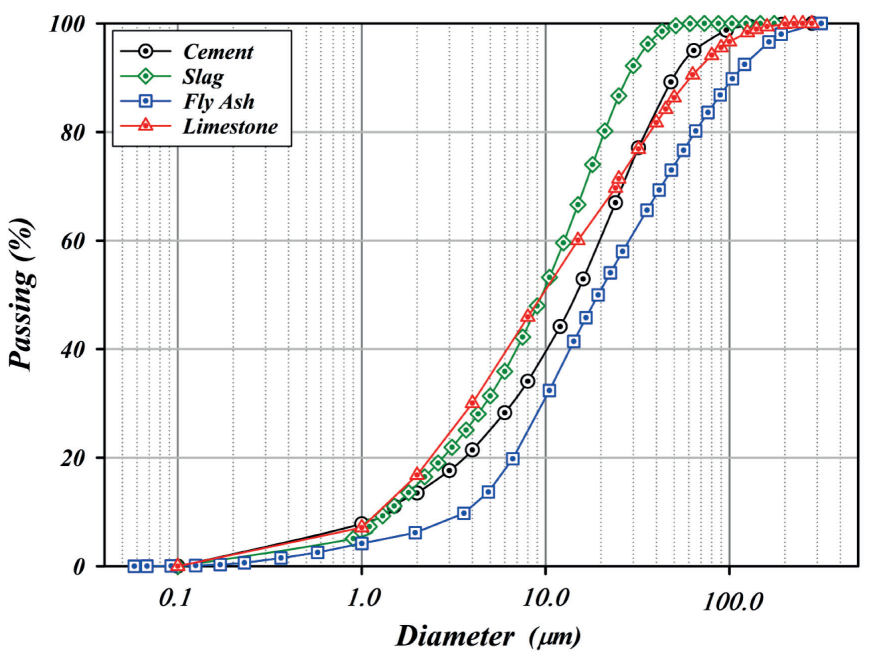

Fig. 1 Particle size distributions of cement and SCMs used

1. ábra A felhasznált cement kiegészítö anyagok és cement szemcse eloszlása

Fig. 2 presents the scanning electron microscopy (SEM) images of OPC, FA, LF and BFS obtained with a microscope at $15.00 \mathrm{kV}$. The morphological characteristics of these powders are clearly shown in this figure. LF presents smaller particles with angular shape and rough surface (Fig. 2d). Both OPC and BFS present more regular particles with smooth surface (Fig. $2 a$ and $2 c$ ). However, FA exhibits spherical shape with slightly larger particles sizes and a smoother surface (Fig. 2d).

\subsection{Mix proportioning}

In this work, four series of cement mortars were produced:

- Series A, B and C have of 10 to $60 \%$ per step of $10 \%$ of OPC weight replaced by FA, BFS and LF respectively, with a control cement mortar without SCMs for the three series. This replacement level was adopted in order to have a high volume of SCM in the cement mortar. A polycarbonate-based SP was used just to maintain the stability of the mixes;

- Series D of SP has of 0.2 to $0.8 \%$, per step of $0.2 \%$, with a control cement mortar without admixture. This dose level was adopted in order to have an ordinary cement mortar. A total, 32 cement mortar samples were made for testing.

Note that, the water to binder ratio (cement plus SCM) is 
equal to 0.37 for the SCMs series and 0.40 for admixtures series. The details of the mixing proportions are presented in Table 3.

\begin{tabular}{|c|c|c|c|c|}
\hline Element (\%) & OPC & FA & BFS & $\mathbf{L F}$ \\
\hline $\mathrm{S}_{1} \mathrm{O}_{2}$ & 20.23 & 50.00 & 35.90 & 0.30 \\
\hline $\mathrm{Al}_{2} \mathrm{O}_{3}$ & 04.29 & 29.00 & 11.20 & - \\
\hline $\mathrm{Fe}_{2} \mathrm{O}_{3}$ & 02.35 & 08.50 & 00.30 & - \\
\hline $\mathrm{T}_{\mathrm{i}} \mathrm{O}_{2}$ & 00.25 & 01.00 & 00.70 & - \\
\hline MnO & 00.02 & 00.50 & 00.40 & - \\
\hline $\mathrm{CaO}$ & 63.67 & 03.00 & 42.30 & - \\
\hline MgO & 03.88 & 03.00 & 08.00 & - \\
\hline $\mathrm{SO}_{3}$ & 02.80 & 00.60 & 00.20 & - \\
\hline $\mathrm{K}_{2} \mathrm{O}$ & 00.69 & 00.60 & - & - \\
\hline $\mathrm{Na}_{2} \mathrm{O}$ & 00.14 & 00.60 & 00.70 & 00.01 \\
\hline $\mathbf{P}_{2} \mathbf{O}_{5}$ & 00.31 & 00.25 & - & - \\
\hline Cl & 00.02 & 00.04 & 00.01 & 00.001 \\
\hline $\mathrm{SO}_{4}$ & - & - & - & 00.011 \\
\hline $\mathrm{CaO}_{3}$ & - & - & - & 98.80 \\
\hline LOI & 01.63 & 04.50 & - & - \\
\hline Activity coefficient & 01.00 & 00.60 & 00.90 & 00.25 \\
\hline Specific density & 03.13 & 02.19 & 02.91 & 02.70 \\
\hline Fineness Blaine $\left(\mathrm{cm}^{2} / \mathrm{g}\right)$ & 4470 & 3930 & 5000 & 4690 \\
\hline Compactness & 00.54 & 00.49 & 00.58 & 00.62 \\
\hline $\mathrm{D}_{10}(\mu \mathrm{m})$ & 01.50 & 03.60 & 01.40 & 01.50 \\
\hline $\mathrm{D}_{50}(\mu \mathrm{m})$ & 15.00 & 19.30 & 10.00 & 10.00 \\
\hline $\mathrm{D}_{90}(\mu \mathrm{m})$ & 48.00 & 104.00 & 28.00 & 63.00 \\
\hline
\end{tabular}

Table 1 Chemical analysis and physical properties of cementitious materials used 1. táblázat A felhasznált anyagok kémiai összetétele és fizikai tulajdonságai

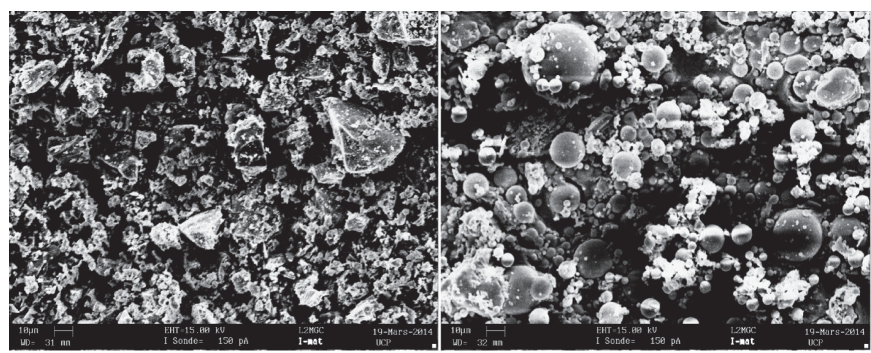

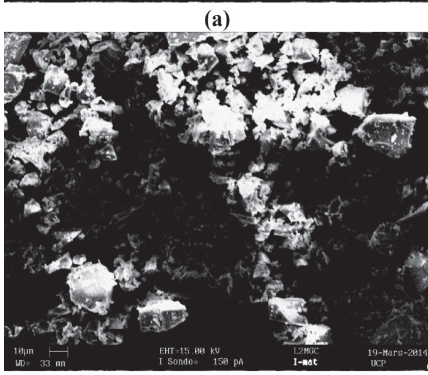

(c)

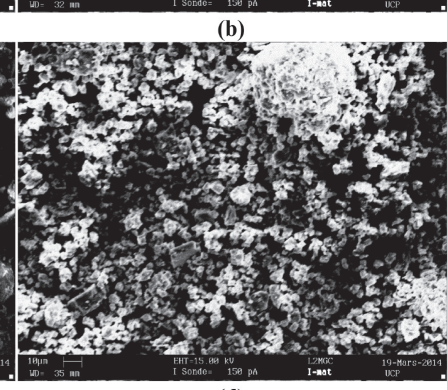

(d)
Fig. 2 SEM images of the materials: (a) OPC, (b) FA, (c) BFS and (d) LF (x2000)

2. ábra A vizsgált anyagok pásztázó elektronmikroszkóppal készült képei: (a) OPC, (b) FA, (c) BFS és (d) LF (x2000)

\subsection{Mixing procedure}

A mixer according to European Standard EN 196-1 [44] at stage I $(62.5 \mathrm{rpm})$ was used to prepare the all fresh cement mortars. The mixing process was kept constant in order to ensure the same homogeneity and uniformity for all mixtures. For the mixes containing SCMs, these additions were previously hand-mixed with the OPC and the necessary water containing SP during $2 \mathrm{~min}$, before adding fine aggregates and mixing for $1 \mathrm{~min}$. The mixing procedure continues for $5 \mathrm{~min}$. Then, the mixture was kept settling for $2 \mathrm{~min}$ before remixing for $1 \mathrm{~min}$.

\begin{tabular}{ccccc} 
Id & Trade name & $\begin{array}{c}\text { Main } \\
\text { characteristic }\end{array}$ & Composition & $\begin{array}{c}\text { Manu- } \\
\text { facturer }\end{array}$ \\
SP1 & Glenium SKY 537 & $\begin{array}{c}\text { SP and high rate } \\
\text { water-reducing }\end{array}$ & $\begin{array}{c}\text { Modified polycar- } \\
\text { boxylic ethers }\end{array}$ & BASF \\
\hline SP2 & $\begin{array}{c}\text { CHRYSO Fluid } \\
\text { Optima 100 }\end{array}$ & $\begin{array}{c}\text { New generation } \\
\text { SP }\end{array}$ & $\begin{array}{c}\text { Modified phospho- } \\
\text { nate }\end{array}$ & CHRYSO \\
\hline SP3 & Glenium ACE 456 & $\begin{array}{c}\text { SP and high rate } \\
\text { water-reducing }\end{array}$ & $\begin{array}{c}\text { New generation of } \\
\text { polycarboxylates }\end{array}$ & BASF \\
& & &
\end{tabular}

Table 2 Properties and composition of admixtures (SP) used 2. táblázat A felhasznált adalékszerek (SP) tulajdonságai és összetétele

\subsection{Test methods}

The workability properties of mortars tested were determined immediately after mixing. Before starting the rheological test, the slump flow test according to standard EN 12350-2 [45] is performed as an empirical test.

The rheological test was conducted using a rheometer developed by Soualhi et al. [46]. It is a rotational rheometer model where four-bladed vane geometry rotates with axial symmetry at a variable speed. The agitator characteristics are: rotational speed from 4 to $540 \mathrm{rpm}( \pm 1 \mathrm{rpm})$ and maximum torque of $740 \mathrm{Ncm}( \pm 0.1 \mathrm{Ncm})$. It is operated by a computer using software (watch \& control). Fig. 3 presents the dimensions of the vane and the container.

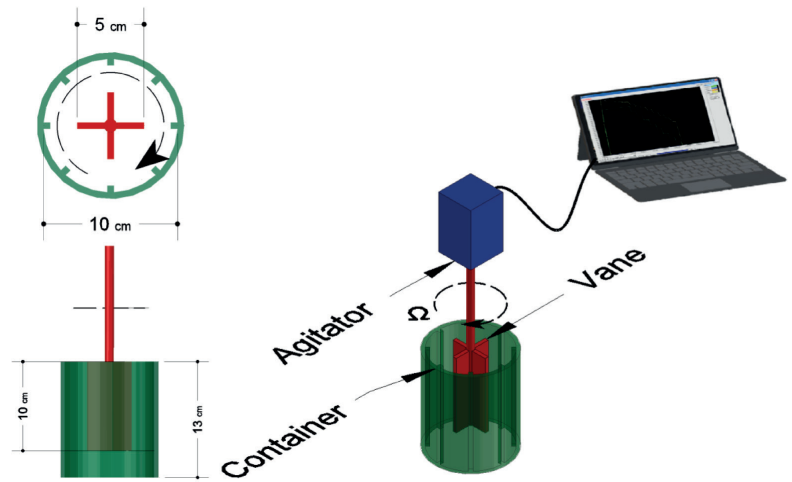

Fig. 3 Rheometer and position of the vane in cement mortar container 3. ábra Reométer és a lapát elhelyezése a cementhabarcs tartályában

The principle is to rotate at different speeds a vane in a cylindrical sample of fresh cement mortar and measuring the torques applied to maintain rotation. A rheological test is performed by imposing a decreasing rotational speed to the vane interrupted by a stabilization stage in order to perform the measurements (Fig. 4). 


\begin{tabular}{|c|c|c|c|c|c|c|c|c|c|c|}
\hline \multirow{7}{*}{ Limestone } & Control & 0.426 & \multirow{7}{*}{0.37} & 616.6 & \multirow{7}{*}{227.4} & 0.0 & 0.0 & & 5.0 & \multirow{7}{*}{1377} \\
\hline & M LF1 & 0.429 & & 555.0 & & 10.0 & 61.7 & \multirow{6}{*}{1.4} & 9.0 & \\
\hline & M LF2 & 0.432 & & 493.3 & & 20.0 & 123.3 & & 22.5 & \\
\hline & M LF3 & 0.435 & & 431.6 & & 30.0 & 185.0 & & 26.0 & \\
\hline & M LF4 & 0.438 & & 370.0 & & 40.0 & 246.6 & & 28.5 & \\
\hline & M LF5 & 0.441 & & 308.3 & & 50.0 & 308.3 & & 34.0 & \\
\hline & M LF6 & 0.444 & & 246.6 & & 60.0 & 370.0 & & 38.0 & \\
\hline \multirow{7}{*}{ Fly ash } & Control & 0.426 & \multirow{7}{*}{0.37} & 616.6 & \multirow{7}{*}{227.4} & 0.0 & 0.0 & & 5.0 & \multirow{7}{*}{1377} \\
\hline & M FA1 & 0.435 & & 555.0 & & 10.0 & 61.7 & & 7.0 & \\
\hline & M FA2 & 0.443 & & 493.3 & & 20.0 & 123.3 & & 9.5 & \\
\hline & M FA3 & 0.451 & & 431.6 & & 30.0 & 185.0 & 1.4 & 11.5 & \\
\hline & M FA4 & 0.459 & & 370.0 & & 40.0 & 246.6 & & 22.5 & \\
\hline & M FA5 & 0.468 & & 308.3 & & 50.0 & 308.3 & & 24.0 & \\
\hline & M FA6 & 0.476 & & 246.6 & & 60.0 & 370.0 & & 29.5 & \\
\hline \multirow{7}{*}{ Slag } & Control & 0.426 & \multirow{7}{*}{0.37} & 616.6 & \multirow{7}{*}{227.4} & 0.0 & 0.0 & \multirow{7}{*}{1.4} & 5.0 & \multirow{7}{*}{1377} \\
\hline & M S1 & 0.428 & & 555.0 & & 10.0 & 61.7 & & 7.5 & \\
\hline & M S2 & 0.429 & & 493.3 & & 20.0 & 123.3 & & 9.5 & \\
\hline & M S3 & 0.430 & & 431.6 & & 30.0 & 185.0 & & 11.5 & \\
\hline & M S4 & 0.432 & & 370.0 & & 40.0 & 246.6 & & 22.5 & \\
\hline & M S5 & 0.433 & & 308.3 & & 50.0 & 308.3 & & 24.0 & \\
\hline & M S6 & 0.434 & & 246.6 & & 60.0 & 370.0 & & 29.5 & \\
\hline \multirow{5}{*}{ SP 1} & MO & \multirow{5}{*}{0.397} & \multirow{5}{*}{0.4} & \multirow{5}{*}{550} & \multirow{5}{*}{220} & \multirow{5}{*}{0} & \multirow{5}{*}{0} & 0 & 6.5 & \multirow{5}{*}{1566.7} \\
\hline & M SKY 02 & & & & & & & 0.2 & 9.5 & \\
\hline & M SKY 04 & & & & & & & 0.4 & 11.5 & \\
\hline & M SKY 06 & & & & & & & 0.6 & 13.5 & \\
\hline & M SKY 08 & & & & & & & 0.8 & 14.5 & \\
\hline \multirow{5}{*}{ SP 2} & MO & \multirow{5}{*}{0.397} & \multirow{5}{*}{0.4} & \multirow{5}{*}{550} & & & & 0 & 6.5 & \\
\hline & M OPT 02 & & & & & & & 0.2 & 12.0 & \\
\hline & M OPT 04 & & & & 220 & 0 & 0 & 0.4 & 15.0 & 1566.7 \\
\hline & M OPT 06 & & & & & & & 0.6 & 15.0 & \\
\hline & M OPT 08 & & & & & & & 0.8 & 15.0 & \\
\hline & M O & & & & & & & 0 & 6.5 & \\
\hline & M ACE 02 & & & & & & & 0.2 & 10.0 & \\
\hline SP 3 & M ACE 04 & 0.397 & 0.4 & 550 & 220 & 0 & 0 & 0.4 & 12.0 & 1566.7 \\
\hline & M ACE 06 & & & & & & & 0.6 & 13.0 & \\
\hline & M ACE 08 & & & & & & & 0.8 & 13.5 & \\
\hline
\end{tabular}

*: for a slump greater than $15 \mathrm{~cm}$, the flow diameter is measured using the mini-slump test.

Table 3 Mix proportions for $1 \mathrm{~m}^{3}$ of cement mortar

3. táblázat $1 \mathrm{~m}^{3}$ habarcs összetétele

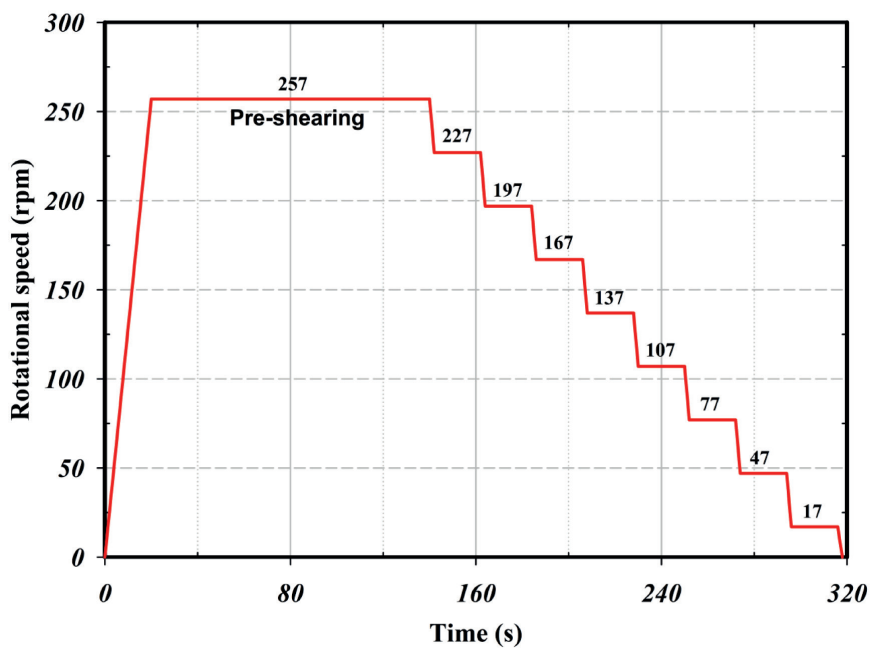

Fig. 4 The profile of the imposed rotational speed 4. ábra A forgási sebesség profilja
The results of the rheometer test are in the form of a linear function relating the torque and the rotational speed according the Eq. (1):

$\mathrm{M}=\mathrm{M}_{0}+\mathrm{k} . \Omega$

Where: $M(\mathrm{Nm})$ total torque applied to the concrete, $M_{0}(\mathrm{Nm})$ torque at the origin, $k(\mathrm{Nms})$ coefficient of proportionality, and $\Omega(\mathrm{rpm})$ speed of rotation of the vane.

In order to develop the rheological parameters from measurements, a procedure was used to convert the vane torque and rotational velocity data into shear stress versus shear rate relationships. The method used considered the locally sheared material as a Bingham fluid (Eq. (2)) and determined the characteristic shear rate from Couette analogy [47].

$\tau=\tau_{0}+\mu \dot{\gamma}$

Where: $\tau$ is the shear stress applied to the material; $\tau_{0}$ the yield stress (minimum stress necessary for flow to occur: interaction of the linear curve with the shear stress axis); $\mu$ the plastic 
viscosity (slope of the linear curve given by the plot of shear stress versus shear rate) and $\dot{\gamma}$ is the shear rate.

The shear rate is expressed by Eqs. (3) and (4):

$\dot{\gamma}=\dot{\gamma}_{1}=2 M \frac{\partial \Omega}{\partial M}$ if $\tau_{c} \leq \tau_{0} \leq \tau_{b}$

$\dot{\gamma}=\dot{\gamma}_{2}=2 \frac{M \frac{\partial \Omega}{\partial M}}{\left(1-\frac{R_{b}^{2}}{R_{c}^{2}}\right)}-\frac{\Omega-M \frac{\partial \Omega}{\partial M}}{\ln \left(\frac{R_{b}}{R_{c}}\right)}$ if $\tau_{c}>\tau_{0}$

Then, the characteristic shear rate is defined as:

$\dot{\gamma}=\max \left(\dot{\gamma}_{1} ; \dot{\gamma}_{2}\right)$

The derivative $\mathrm{d} \Omega / \mathrm{dM}$ in Eqs. (3) and (4) can be approximated by Eq. (6):

$\frac{\partial \Omega_{j}}{\partial M_{j}} \cong \frac{\Omega_{j+1}-\Omega_{j}}{M_{j+1}-M_{j}} ; j=\overline{1, n}$

The shear rate corresponding to the rotation speed $\Omega_{\mathrm{j}}(\mathrm{i}=\mathrm{j})$ can be calculated by Eq. (7):

$\dot{\gamma}_{i}=\max \left(\dot{\gamma}_{1 j} ; \dot{\gamma}_{2 j}\right)$ where $i=j$ and $j=\overline{1, n}$

Once the shear rate has been estimated by Eq. (7), it is deemed to correspond to the following wall shear stress (Eq. (8)):

$\tau_{i}=\frac{1}{2}\left(\tau_{j}+\tau_{j+1}\right)$ avec $: \tau_{j o u j+1}=\frac{M_{j o u} j+1}{2 \pi h R_{b}^{2}} ; i=j$ et $j=\overline{1, n}(8)$

Also, $M_{j}$ and $M_{j+1}$ are calculated by Eq. (9):

$M_{i}=M_{t, i}-M_{v, i}$

Where: $i$ is the indication of speed level, $M_{t, i}$ the average of total measured torque for each level when the container is filled with cement mortar, and $M_{v, i}$ the average of measured torques for each level when the container is empty (without cement mortar).

Eqs. (7) and (8) allow drawing the shear stress curves $\tau(\mathrm{Pa})$ according to the shear rate $\dot{\gamma}(1 / \mathrm{s})$ and estimating then the rheological parameters $\tau_{0}$ and $\mu$.

However, the maximum solid concentration of the powder $\left(\Phi^{*}{ }_{\text {paste }}\right)(\mathrm{OPC}+\mathrm{SCM})$ is measured with test water demand [48]. Whereas, the solid volume of paste $(\Phi)$ is calculated using Eq. (10): $\emptyset=\frac{V_{C}+V_{S C M}}{V_{C}+V_{S C M}+V_{W}+V_{S P}}$

Where: $V_{C^{\prime}} V_{S C M}, V_{W^{*}}, V_{S P}$ are respectively the volumes of cement, SCM, water and SP.

\section{Results and discussion}

3.1 Rheological properties of limestone fillers based mortar

The rheological properties of SCM based mortar, under the same conditions, were followed in order to understand its behavior at fresh state. The effect of partial cement replacement by LF on the rheological properties and relative solid concentration of cement mortar is shown in Fig. 5 and Table 4. The Fig. 5. $a$ shows that the incorporation of LF reduces the yield stress and the plastic viscosity of cement mortar in an approximately linear way. However, it can be seen that, the rheological properties are not influenced when using 10 to $30 \%$ of LF in mixtures. Then, both properties decrease more for up to $60 \%$ of LF. These results are in agreement with those reported in previous studies $[19,25]$. It should be noted that, this research work does not disclose contradictory results with those reported in the study conducted by Safiddine [27]. In the present work, the LF used was a powder produced by direct grinding of limestone and its addition was made by replacement of the cement. While, the authors in reference [27], have used a quarry waste limestone powder and have incorporated LF as a replacement of crushed sand, where the specific surface of the sand is much smaller than that of LF. Even, these results are in good agreement with those found by Felekoglu [38,39]. It should be noted that, the physical effect, such as particle size distribution and compactness, is clear on the obtained results of rheological properties of mixtures made with LF. Apparently, in this situation, the effect of the morphology of the LF particles on the rheology of the cement mortar is more dominant than the effect of their specific surface. In fact, since the cement mortar contains a SP admixture, it is very important to keep in mind that, once the SP admixture is adsorbed on the surfaces of the particles, the water requirement is no longer a function of the surface to be wet, but of the interparticles space to be filled. According to Panesar and Zhang [3] partly because of the limited availability of SCMs in some geographic regions. This study provides a comprehensive review based on published literature on the properties of cement-based materials (paste, mortar and concrete, LF has physical effect on the behavior of cement by modification the particles size distribution, and leads to the dilution of the paste. The modification of particle size distribution can improve the rheology of concrete, whereas the dilution may have potentially an adverse effect on the fresh and rheological properties of the material. In addition, the ease of grinding of LF compared to the clinker acquires it a large particle size distribution, as shown in Fig. 1. As a result, replacing cement with LF improves particle size distribution of the resulting binder. This allows the LF particles (with average size $\mathrm{D}_{50}=10 \mu \mathrm{m}$ ) to occupy the space between the coarser cement (with average size $D_{50}=15 \mu \mathrm{m}$ ) and sand particles. This results in the release of an amount of water, which is trapped in this space, making it accessible as a supplementary inner lubricant. This leads to increase in the release water and improves the workability of the mortar.

In other words, the quantity of water released reduces the water demand for the same slump, which decreases the plastic viscosity and the yield stress of the cement mortar.

\begin{tabular}{cccccccc} 
Mix & $\begin{array}{c}\text { Lime- } \\
\text { stone } \\
(\%)\end{array}$ & $V_{\text {Paste }}\left(\mathbf{m}^{3}\right)$ & $\Phi_{\text {Paste }}$ & $\Phi^{*}{ }_{\text {Paste }}$ & $\Phi / \Phi^{*}{ }_{\text {Paste }}$ & $\mu($ Pa.s) & $\tau_{0}(\mathrm{~Pa})$ \\
\hline Control & 0.0 & 0.426 & 0.458 & 0.539 & 0.850 & 10.8 & 33.8 \\
\hline MLF1 & 10.0 & 0.429 & 0.462 & 0.542 & 0.853 & 7.6 & 24.1 \\
\hline MLF2 & 20.0 & 0.432 & 0.465 & 0.545 & 0.853 & 7.6 & 23.8 \\
\hline MLF3 & 30.0 & 0.435 & 0.469 & 0.551 & 0.852 & 8.3 & 26.1 \\
\hline MLF4 & 40.0 & 0.438 & 0.472 & 0.559 & 0.845 & 6.0 & 22.4 \\
\hline MLF5 & 50.0 & 0.441 & 0.476 & 0.568 & 0.837 & 5.6 & 21.8 \\
\hline MLF6 & 60.0 & 0.444 & 0.479 & 0.568 & 0.844 & 4.4 & 16.0
\end{tabular}

Table 4 Rheological parameters of limestone fillers based mortar 4. táblázat A mészkö kitöltőanyag alapú habarcs reológiai paraméterei 


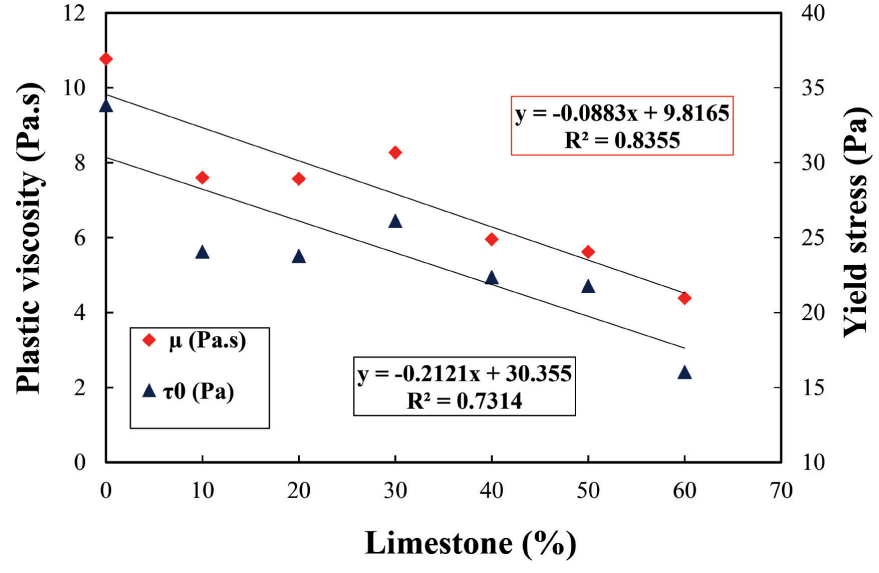

(a)

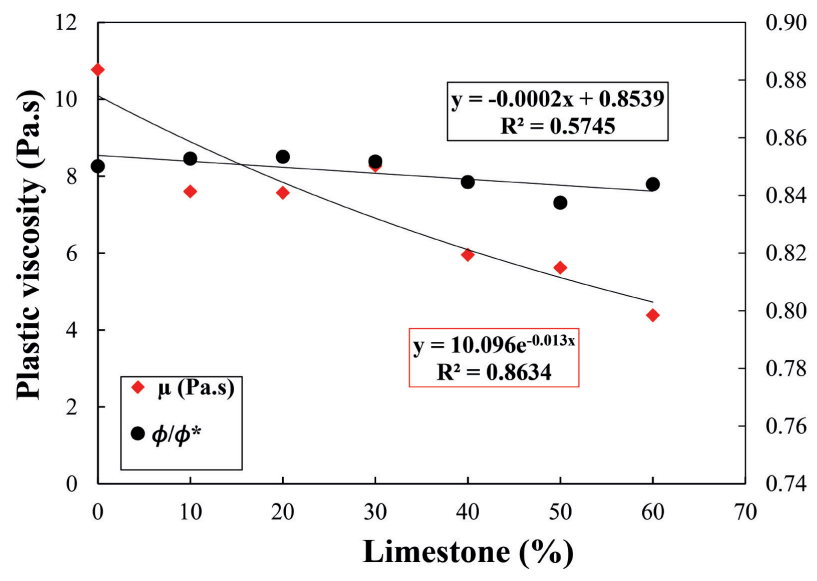

(b)

Fig. 5 Evolution of (a) rheological properties and (b) relative solid concentration with plastic viscosity of limestone fillers based mortar

5. ábra A (a) reológiai tulajdonságok és (b) relatív szilárd koncentráció alakulása a mészkỏ kitöltöanyag alapú habarcs viszkozitásának függvényében

Fig. 5.b and Table 4 show the influence of LF content in cement on the viscosity and the relative solid concentration of the cement paste (without sand). From Fig. 5 it is revealed that, the influence of the Lf on the viscosity and compactness of mortar is quite logical, although it can be poorly explained. Since the decrease in the $\phi / \phi^{*}$ ratio is due to the increase in $\phi^{*}$ and not to the decrease in $\phi$. According to Table 4, these last two parameters increase simultaneously with the increase of the LF, due to the higher compactness of LF compared to that of cement as seen in Table 1. Therefore, decreasing this ratio could mean that the distance between particles is increasing, which increases their mobility by reducing friction and reduces the rheological parameters of the cement mortar. This argues well for the interpretation given previously regarding the effect of LF on the rheology of the cement mortar.

According to Hawkins et al. [40] heat evolution, microstructure, and setting time. The properties of hardened mortar and concrete made with limestone portland cement are examined and compared to those made with non-limestone portland cements-including compressive and flexural strength, volume stability, durability (permeability, carbonation, freeze/thaw resistance, sulfate and chloride resistance, and alkali-silica reaction, the influence of LF on rheology could be more pronounced, if the hydration reaction is delayed by the low reactivity of LF (coefficient of reactivity 0.25) compared to cement. However, the chemical effect of LF is far from being present here, because the tests were carried out in the first 30 minutes, i.e.: before the start of setting of the cement.

\subsection{Rheological properties of fly ash based mortar}

The evolution of the yield stress and plastic viscosity of FA based mortars is shown in Fig. 6. From Fig. 6a, it is shown that, the yield stress increases exponentially with an increase in FA replacement level. Likewise, the plastic viscosity increases linearly with an increase in percentage of FA. According to Koehler and Fowler [49], there are two conflicting mechanisms that influence the workability of concrete with FA. As the FA particles are much smaller than the cement particles, for which they replace them, the area to be wetted is increased. Hence, the workability is reduced. However, the spherical shape of the FA particles produces a bearing that allows larger particles to flow more easily and improves the workability of the mixture. The spherical shape of the FA particles has the smallest specific surface area compared to other SCMs used (Table 1). This does not lead to a reduction in the rheological properties of the cement mortar, contrary to what is expected. The use of FA is generally recognized to reduce the yield stress, but has varying effects on plastic viscosity [49]. However, there are also some researchers, $[4,13,29]$ the mixture's rheological parameters should be adjusted to achieve a given profile of yield stress and plastic viscosity. Supplementary cementitious materials (SCM, who have found that FA increases the rheological properties of concrete.

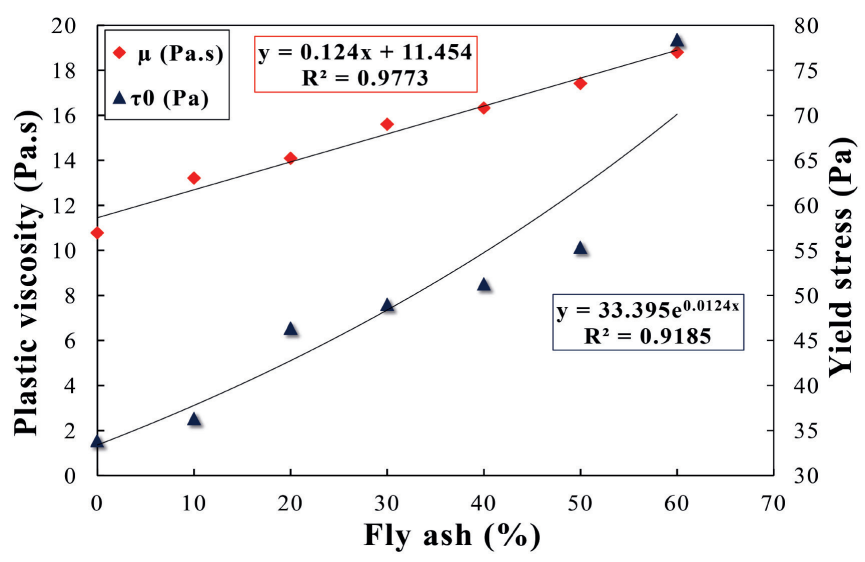

(a)

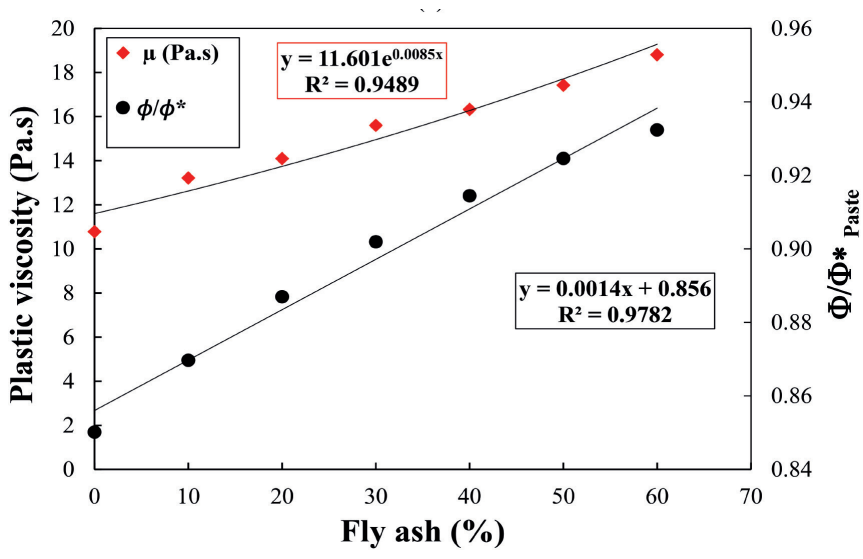

(b)

Fig. 6 Evolution of (a) rheological properties and (b) relative solid concentration with plastic viscosity of flay ash based mortar.

6. ábra $A(a)$ reológiai tulajdonságok és (b) relatív szilárd koncentráció alakulása a pernye alapú habarcs viszkozitásának függvényében 
In this study, the rheological behavior of the FA based mortar could be explained in physical manner using the evolution of $\phi / \phi^{*}$ ratio, as shown in Fig. $6 . b$ and Table 5. The density of FA $\left(2190 \mathrm{~kg} / \mathrm{m}^{3}\right)$, which is slightly lower than that of cement $\left(3130 \mathrm{~kg} / \mathrm{m}^{3}\right)$, increases the solid volume of the paste by a rate of about $43 \%$, with the same mass replaced. This is expressed in the increase in $\phi$ (Table 5) and $\phi / \phi^{\star}$ ratio of cement mortar. According to Roussel [50], as the fraction of solid volume increases, the viscosity of cement-based materials increases exponentially until it reaches infinity, while the fraction of solid volume approaches to a maximum value. This is exactly what happened with the increase in the rate of cement replacement with FA. The evolution in viscosity is due to the decrease in interparticle distance, which contributes to a significant increase in the interparticle hydrodynamic forces.

\begin{tabular}{lccccccc} 
Mix & $\begin{array}{c}\text { Fly ash } \\
(\%)\end{array}$ & $\mathbf{V}_{\text {Paste }}\left(\mathbf{m}^{3}\right)$ & $\Phi_{\text {Paste }}$ & $\Phi^{*}{ }_{\text {Paste }}$ & $\Phi / \Phi_{\text {Paste }}^{*}$ & $\mu(\mathrm{Pa} . \mathbf{s})$ & $\tau_{0}(\mathrm{~Pa})$ \\
\hline M T & 0.0 & 0.426 & 0.458 & 0.539 & 0.850 & 10.8 & 33.8 \\
\hline MFA1 & 10.0 & 0.435 & 0.468 & 0.538 & 0.870 & 13.2 & 36.3 \\
\hline MFA2 & 20.0 & 0.443 & 0.478 & 0.539 & 0.887 & 14.1 & 46.4 \\
\hline MFA3 & 30.0 & 0.451 & 0.487 & 0.540 & 0.902 & 15.6 & 49.0 \\
\hline MFA4 & 40.0 & 0.459 & 0.496 & 0.543 & 0.914 & 16.3 & 51.3 \\
\hline MFA5 & 50.0 & 0.468 & 0.505 & 0.546 & 0.925 & 17.4 & 55.3 \\
\hline MFA6 & 60.0 & 0.476 & 0.514 & 0.551 & 0.932 & 18.8 & 78.4
\end{tabular}

Table 5 Rheological parameters of fly ash based mortar 5. táblázat A pernye alapú habarcs reológiai paraméterei

\subsection{Rheological properties of slag based mortar}

Fig. 7 and Table 6 show the evolution of the rheological behavior of the cement mortar through the measurement of the plastic viscosity and the yield stress and they give the variation of $\phi / \phi^{\star}$ ratio up to $60 \%$ replacement of cement by BFS. From Fig. 7.a, it is noted that, the yield stress increases for mass replacement of the BFS up to $40 \%$, and decreases for $50 \%$ and $60 \%$ of BFS. However, it remains higher compared to that of the control cement mortar without BFS. Furthermore, the plastic viscosity increases in an approximately linear way with an increase in mass replacement of BFS in the cement mortar as shown in Fig. 7.b. These results are in agreement with some previous studies $[13,30]$. The same interpretation could be given as with FA, except that in the case of BFS this result was expected, with shape, size, specific surface, particle size distribution and density of BFS. The use of BFS in general improves workability and its effect on yield stress is variable, while increases plastic viscosity [49]. Indeed, this is what is noted from Table 3, the slump increases as well as the plastic viscosity and the yield stress. This is may be due to an increase in viscosity, which means that the viscosity has an impact on the yield stress [51].

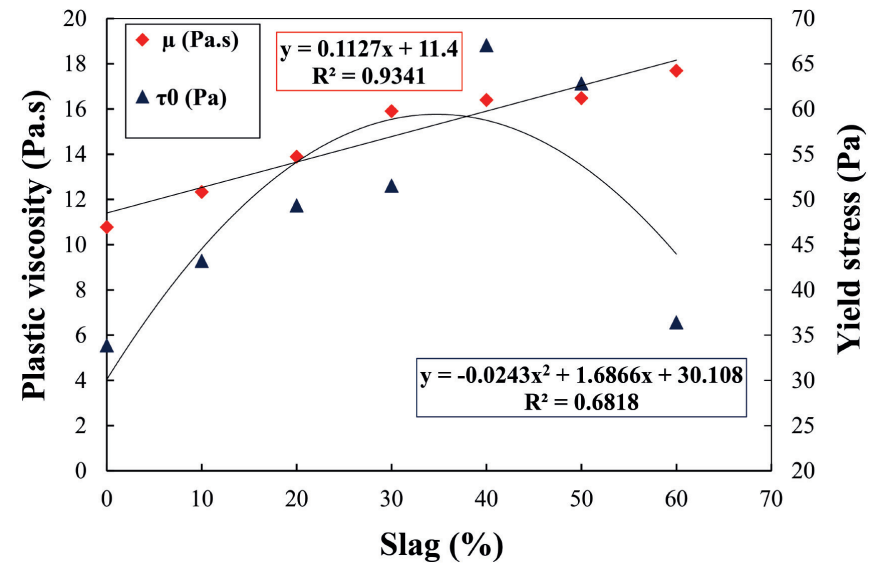

(a)

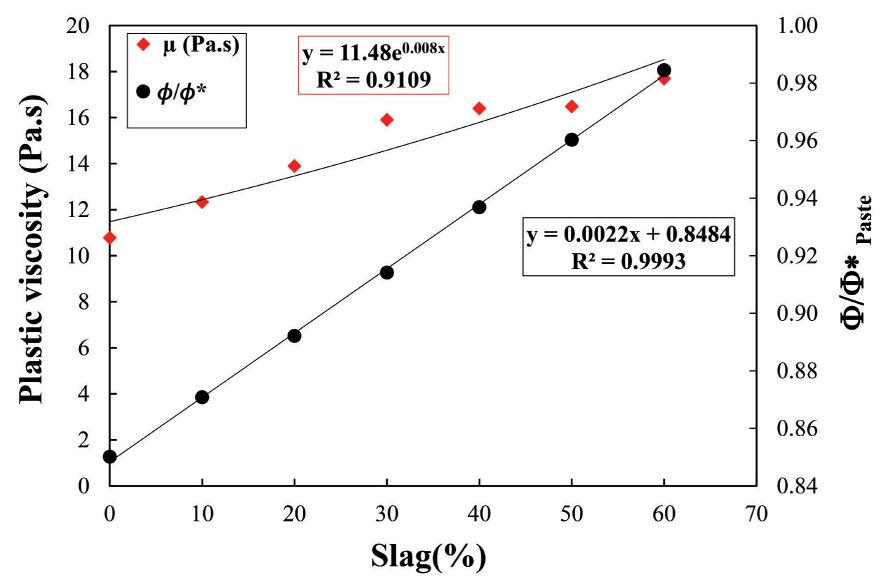

(b)

Fig. 7 Evolution of (a) rheological properties and (b) relative solid concentration with plastic viscosity of slag based mortar

7. ábra A (a) reológiai tulajdonságok és (b) relatív szilárd koncentráció alakulása a salak alapú habarcs viszkozitásának függvényében

Mix Slag (\%) $\mathbf{V}_{\text {Paste }}\left(\mathrm{m}^{3}\right) \quad \Phi_{\text {Paste }} \Phi^{*}{ }_{\text {Paste }} \Phi / \Phi^{*}$ Paste $^{\mu} \mu(\mathrm{Pa} . \mathrm{s}) \quad \tau_{0}(\mathrm{~Pa})$

\begin{tabular}{lccccccc} 
M T & 0.0 & 0.426 & 0.458 & 0.539 & 0.850 & 10.8 & 33.8 \\
\hline M S1 & 10.0 & 0.428 & 0.460 & 0.528 & 0.871 & 12.3 & 43.19 \\
\hline M S2 & 20.0 & 0.429 & 0.461 & 0.517 & 0.892 & 13.9 & 49.33 \\
\hline M S3 & 30.0 & 0.430 & 0.463 & 0.506 & 0.914 & 15.9 & 51.5 \\
\hline M S4 & 40.0 & 0.432 & 0.465 & 0.496 & 0.937 & 16.4 & 67.0 \\
\hline M S5 & 50.0 & 0.433 & 0.466 & 0.485 & 0.960 & 16.5 & 62.8 \\
\hline M S6 & 60.0 & 0.434 & 0.468 & 0.475 & 0.984 & 17.7 & 36.4
\end{tabular}

Table 6 Rheological parameters of slag based mortar 6. táblázat A salak alapú habarcs reológiai paraméterei

\subsection{Comparison of rheological behavior of SCM based mortars}

Fig. 8 shows the rheological behavior of cement mortars with 20,40 and $60 \%$ of different SCMs used as cement replacement. At high content of SCM (60\%), it is clear that, LF reduces the rheological properties. In contrast, the BFS and the FA increase the rheological properties, in particular the plastic viscosity. However, according to Figs. 5.a, 6.a and 7.a, it can be seen that, the evolution of the yield stress varies from one SCM to another under the same dosage conditions. Indeed, the evolution of the plastic viscosity is almost superimposed for the FA and the BFS by increasing this parameter. On the contrary, 
the variation of the plastic viscosity takes on another meaning with the LF, which improves this parameter. For this reason, it is very important to combine the effect of LF with other SCMs, to produce ternary cement (OPC-LF-BFS or OPC-LF-FA), in order to improve the rheology of the cement mortar and reduce the release of $\mathrm{CO}_{2}$ in one hand. Also, to fill the gap induced by the decrease in the amount of FA in the near future, due to recent limits on coal combustion in power plants to reduce air pollution. Since, in practice, it is usually important to have a certain viscosity in order to prevent segregation and improve the quality of the cement-based materials thus obtained. This is particularly important with the evolution of admixtures use and long-distance pumping.

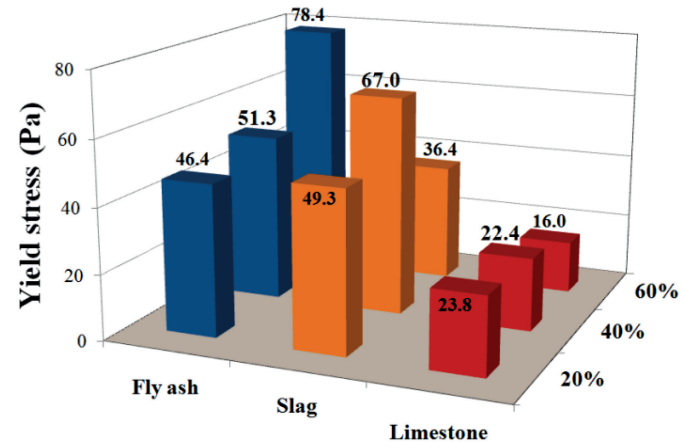

SCMs based mortars

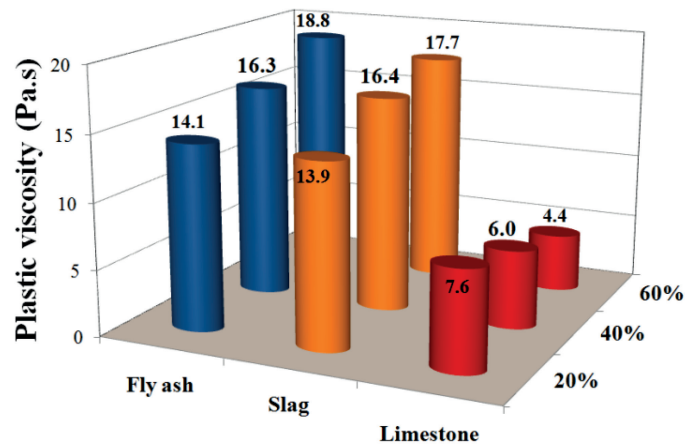

SCMs based mortars

Fig. 8 Comparison of (a) the yield stress and (b) the plastic viscosity of cement mortar with 20,40 and $60 \%$ of SCMs content

8. ábra A cementhabarcs (a) folyási feszültségének és (b) viszkozitásának összehasonlitása 20, 40 és 60\% cement kiegészitö anyag tartalom esetén

\subsection{Relationship between the plastic viscosity of cement mortar and the relative solid concentration}

In this study as shown in Fig. 9, the measured values of plastic viscosity were plotted against the measured values of relative solid concentration of nineteen fresh cement mortars with different SCMs (six mixes for each SCM in addition to the control mortar). According to Roussel [50], the relative solid concentration of fresh paste $\left(\phi / \phi_{\text {paste }}{ }^{*}\right)$ is the ratio of the solid volume of powder $(\phi)$ (i.e. the ratio of the total volume of the powder to the total sample volume of cement mortar) and another critical parameter namely $\left(\phi_{\mathrm{p}_{\text {aste }}}{ }^{*}\right)$; i.e. the maximum solid concentration of powder, which is the maximum volume fraction that can be reached with the grains. Usually, when the solid fraction approaches to $\phi^{*}$, the concentrated regime is established and the viscosity tends to infinity.

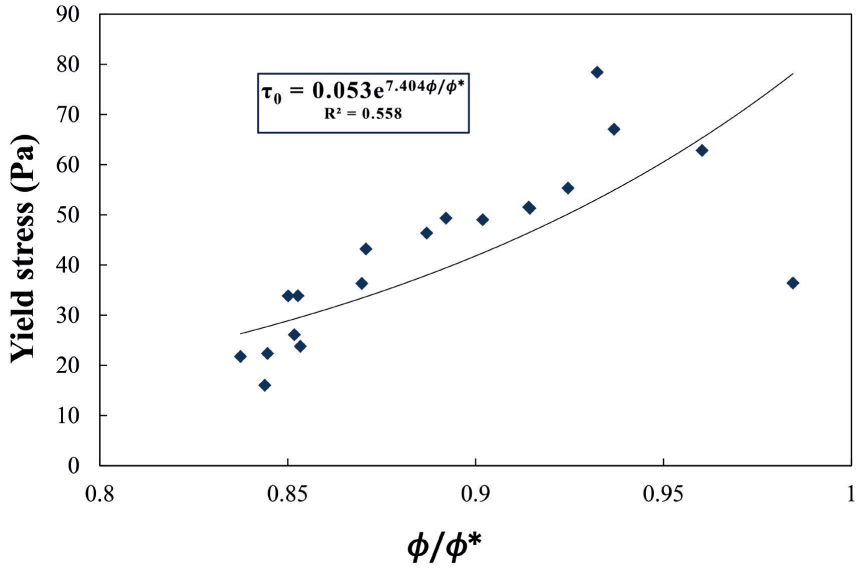

(a)

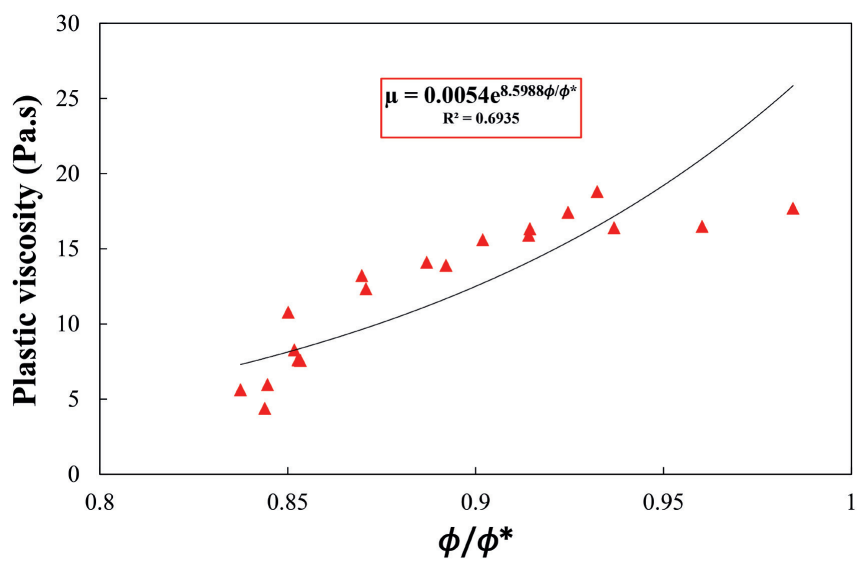

(b)

Fig. 9 Relationship between relative solid concentration (a) the yield stress; (b) the plastic viscosity of SCMs based mortar

9. ábra A cement kiegészitő anyag alapú habarcs relatív szilárd koncentrációjának kapcsolata (a) a folyási feszültséggel; b) viszkozitással

Fig. 9. $a$ indicates the good relationship between the relative solid concentration and the yield stress. Similarly, Fig. 9.6 shows a reasonable relationship between the relative solid concentration and the plastic viscosity. It is concluded that, the trend of yield stress is similar to that of plastic viscosity for all mixtures with the different SCMs used. The increase in relative solid concentration increased the rheological properties regardless the SCM used. Similar results have been reported by previous studies on rheological behavior of concrete.

\subsection{Influence of superplasticizer admixture type and dosage}

As shown in Fig. 10 that, the rheological behavior of cement mortar each type of admixture is affected differently by each type of admixture. At least for dosages of less than $1 \%$, the SP based on modified phosphonate (SP2) has better efficiency than the admixtures based on polycarboxylates (SP1 and SP3), which results in reducing the rheological properties of the cement mortar. However, its effectiveness decreases as the dosage increases, unlike SP1 and SP3, which reduces the rheological properties, in particular the plastic viscosity.

It is reported that, the phosphonates are organophosphorus compounds containing $\mathrm{C}-\mathrm{PO}(\mathrm{OH})_{2}$ or $\mathrm{C}-\mathrm{PO}(\mathrm{OR})_{2}$ groups (where $\mathrm{R}=\mathrm{alkyl}$, aryl), while the polycarboxylates are linear polymers. According to Criado et al. [52], organic admixtures 
based on both hydrophilic and hydrophobic group. The electrical charge resulting from the adsorption of these compounds on the surface of cement particles induces the repulsive forces that increase fluidity of the paste. However, the lateral chains in admixtures based on polycarboxylates generate steric repulsion among the cement grains, causing deflocculation and dispersion of the particles, which in turn improves workability by releasing the water trapped in the flocs, which results in decreasing the slump of the cement mortars (Table 3).

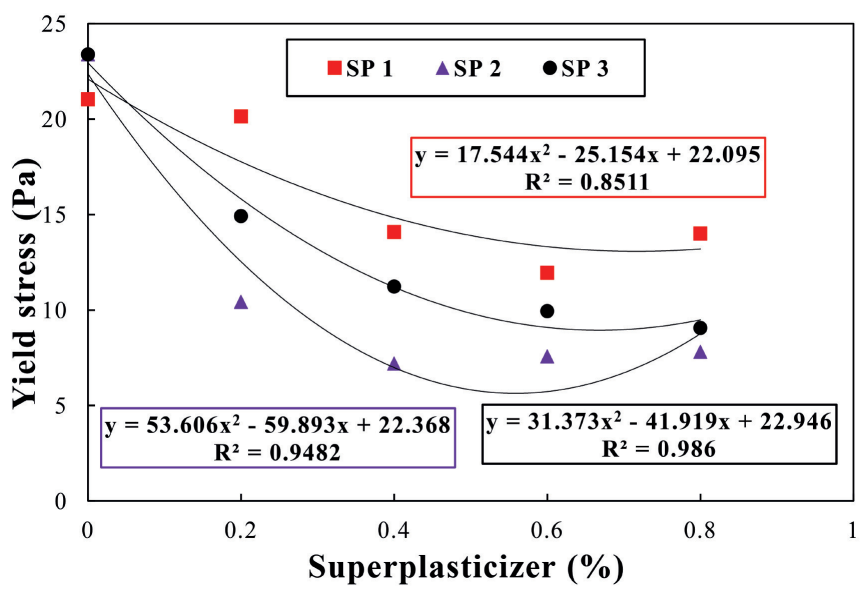

(a)

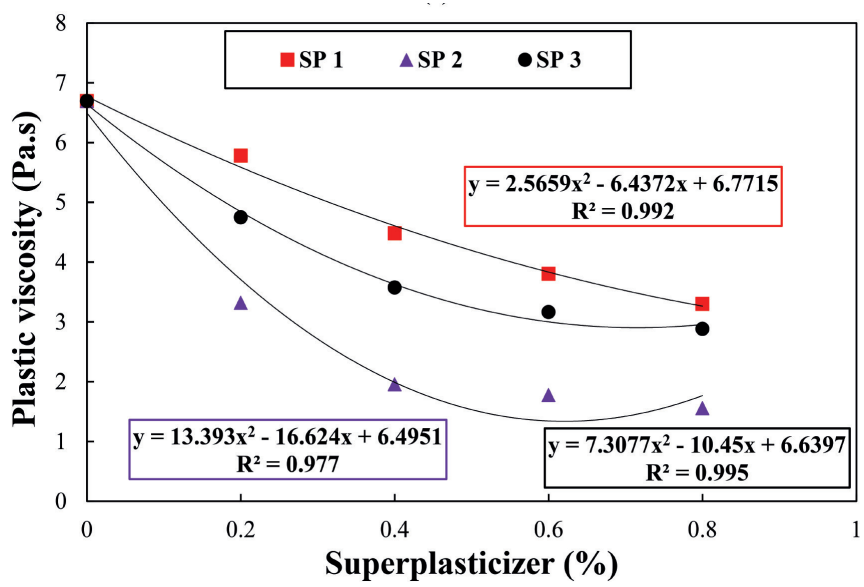

(b)

Fig. 10 Influence of SP admixtures on: (a) the yield stress and (b) the plastic viscosity 10. ábra Az SP adalékszerek hatása a: (a) a folyási feszültségre és (b) a viszkozitásra

The results show that, the dosage of $0.2 \%$ for SP2 results in a similar effect to the dosage of $0.6 \%$ for SP3 and better than the dosage of $0.8 \%$ for SP1. However, beyond $0.4 \%$, SP2 has become steadily less efficient compared to SP1 and SP3. This is may be due of the steric effect of polycarboxylates, which has become more and more dominant as the dosage increases.

\section{Conclusions}

The rheology of cement mortars containing three SCMs (LF, FA, BFS) and three different SP admixture types is compared based on an evolution of the plastic viscosity and the yield stress of the control mix without SCMs and SP, respectively. The following conclusions can be drawn from this research work:
- Increasing the amount of LF from 0 to $60 \%$ reduced the yield stress and the plastic viscosity of cement mortar by $52 \%$ and $59 \%$, respectively.

- The cement mortar containing FA or BFS exhibited higher yield stress and plastic viscosity compared to those of the control mortar. In addition, with the use of $60 \%$ of FA, the yield stress and the plastic viscosity increased by $132 \%$ and $75 \%$ respectively.

- At a replacement level up to $40 \%$ of BFS, the yield stress of cement mortar increased with a rate of $98 \%$. However, for a replacement level of 50 to $60 \%$, the yield stress is decreased. When using $60 \%$ of BFS, an improvement rate of about $8 \%$ and $64 \%$ for the yield stress and the plastic viscosity is recorded, respectively

- Cement mortar incorporating FA has similar behavior in increasing the plastic viscosity compared to that of cement mortar containing BFS.

- In addition, the obtained results confirm the compatibility of the incorporation of SP with LF. This makes the use of the high-volume eco-friendly binder in mortars and concretes very promising in terms of improving workability or reducing the $\mathrm{W} / \mathrm{B}$ ratio for a given slump.

- $\quad$ For dosage less than 1\% of SP, the SP2 based on phosphonate reduced the rheological properties better compared to the SP based on polycarboxylate (SP1 and SP3).

- Dosage of $0.2 \%$ of SP 2 had an equivalent effect to that when using dosage of $0.8 \%$ of SP 1 and $0.6 \%$ of SP3, in terms of reducing the rheological properties of the cement mortar.

- In the same way, the steric effect of polycarboxylates became more and more dominant as the dosage of SP increases.

This study provides a reference for use of FA, BFS and LF to develop green building materials with the desired rheological properties. Overall, LF can be used to produce the low rheological properties cement mortar. While, FA and BFS can be used for the production of high rheological properties cement mortar. This helps to reduce the high cement consumption in the production of cement-based materials and contributes to environmental sustainability and resource savings.

In this regard, it is recommended that, this study to be accompanied by scientific investigations on combining LF with the BFS and the FA, with a high percentage of the LF, in order to have the sufficient rheological properties for different applications and different types of concrete, in particular self-compacting concrete. Moreover, future research is recommended in order to study the synergistic effect of these additions on the rheology of ternary and quaternary cementitious blends-based materials.

\section{Acknowledgements}

The authors gratefully acknowledge the Directorate-General of Scientific Research and Technological Development of Algeria (DGRSDT) for its valuable support. 


\section{References}

[1] J. Ofosu-Adarkwa, N. Xie, S.A. Javed, Forecasting CO2 emissions of China's cement industry using a hybrid Verhulst-GM(1,N) model and emissions' technical conversion, Renew. Sustain. Energy Rev. 130 (2020) 109945. https://doi.org/10.1016/j.rser.2020.109945.

[2] J. Skibsted, R. Snellings, Reactivity of supplementary cementitious materials (SCMs) in cement blends, Cem. Concr. Res. 124 (2019) 105799. https://doi.org/10.1016/j.cemconres.2019.105799.

[3] D.K. Panesar, R. Zhang, Performance comparison of cement replacing materials in concrete: Limestone fillers and supplementary cementing materials - A review, Constr. Build. Mater. 251 (2020) 118866. https://doi.org/10.1016/j.conbuildmat.2020.118866.

[4] E. Ghafari, S. Ghahari, D. Feys, K. Khayat, A. Baig, R. Ferron, Admixture compatibility with natural supplementary cementitious materials, Cem. Concr. Compos. 112 (2020) 103683. https://doi.org/10.1016/j.cemconcomp.2020.103683.

[5] S.H. Kang, Y. Jeong, K.H. Tan, J. Moon, High-volume use of limestone in ultra-high performance fiber-reinforced concrete for reducing cement content and autogenous shrinkage, Constr. Build. Mater. 213 (2019) 292305. https://doi.org/10.1016/j.conbuildmat.2019.04.091.

[6] V.M. John, B.L. Damineli, M. Quattrone, R.G. Pileggi, Fillers in cementitious materials - Experience, recent advances and future potential, Cem. Concr. Res. 114 (2018) 65-78. https://doi.org/10.1016/j.cemconres.2017.09.013.

[7] A.M. Rashad, W.M. Morsi, S.A. Khafaga, Effect of limestone powder on mechanical strength, durability and drying shrinkage of alkaliactivated slag pastes, Innov. Infrastruct. Solut. 6 (2021) 1-12. https://doi.org/10.1007/s41062-021-00496-y.

[8] P. Turgut, A. Ogretmen, Optimum limestone powder amount in mortars with over silica fume, Epa. - J. Silic. Based Compos. Mater. 71 (2019) 5864. https://doi.org/10.14382/epitoanyag-jsbcm.2019.11.

[9] I.D. Uwanuakwa, Deep Learning Modelling and Generalisation of Carbonation Depth in Fly Ash Blended Concrete, Arab. J. Sci. Eng. (2020). https://doi.org/10.1007/s13369-020-05093-2.

[10] A.K.H. Kwan, Y. Li, Effects of fly ash microsphere on rheology, adhesiveness and strength of mortar, Constr. Build. Mater. 42 (2013) 137-145. https://doi.org/10.1016/j.conbuildmat.2013.01.015.

[11] A.Y. K. H. Khayat and M. Sayed, K.H. Khayat, A. Yahia, M. Sayed, Effect of Supplementary Cementitious Materials on Rheological Properties, Bleeding, and Strength of Structural Grout, ACI Mater. J. 105 (2008). https://doi.org/10.14359/20200.

[12] J. Assaad, K.H. Khayat, Assessment of Thixotropy of Self-Consolidating Concrete and Concrete-Equivalent-Mortar - Effect of Binder Composition and Content, ACI Mater. J. 101 (2004) 400-408. https://doi.org/10.14359/13426.

[13] I. Mehdipour, A. Kumar, K.H. Khayat, Rheology, hydration, and strength evolution of interground limestone cement containing PCE dispersant and high volume supplementary cementitious materials, Mater. Des. 127 (2017) 54-66. https://doi.org/10.1016/j.matdes.2017.04.061.

[14] L.A. Qureshi, B. Ali, A. Ali, Combined effects of supplementary cementitious materials (silica fume, GGBS, fly ash and rice husk ash) and steel fiber on the hardened properties of recycled aggregate concrete, Constr. Build. Mater. 263 (2020) 120636.

https://doi.org/10.1016/j.conbuildmat.2020.120636.

[15] P. Narasimha Reddy, B.V. Kavyateja, Durability performance of high strength concrete incorporating supplementary cementitious materials, Mater. Today Proc. 33 (2020) 66-72. https://doi.org/10.1016/j.matpr.2020.03.149.

[16] A. Elahi, P.A.M. Basheer, S. V. Nanukuttan, Q.U.Z. Khan, Mechanical and durability properties of high performance concretes containing supplementary cementitious materials, Constr. Build. Mater. 24 (2010) 292-299. https://doi.org/10.1016/j.conbuildmat.2009.08.045.

[17] S. Tsimas, A. Moutsatsou-Tsima, High-calcium fly ash as the fourth constituent in concrete: Problems, solutions and perspectives, Cem. Concr. Compos. 27 (2005) 231-237. https://doi.org/10.1016/j.cemconcomp.2004.02.012.

[18] Y. Du, W. Yang, Y. Ge, S. Wang, P. Liu, Thermal conductivity of cement paste containing waste glass powder, metakaolin and limestone filler as supplementary cementitious material, J. Clean. Prod. (2020) 125018 https://doi.org/10.1016/j.jclepro.2020.125018.

[19] J. Wang, J. Xie, Y. Wang, Y. Liu, Y. Ding, Rheological properties, compressive strength, hydration products and microstructure of seawater-mixed cement pastes, Cem. Concr. Compos. 114 (2020) 103770. https://doi.org/10.1016/j.cemconcomp.2020.103770.

[20] Z. Yingliang, Q. Jingping, M.A. Zhengyu, G. Zhenbang, L. Hui, Effect of superfine blast furnace slags on the binary cement containing highvolume fly ash, Powder Technol. 375 (2020) 539-548. https://doi.org/10.1016/j.powtec.2020.07.094.

[21] S. Cheng, Z. Shui, T. Sun, R. Yu, G. Zhang, Durability and microstructure of coral sand concrete incorporating supplementary cementitious materials, Constr. Build. Mater. 171 (2018) 44-53. https://doi.org/10.1016/j.conbuildmat.2018.03.082.

[22] J.Y. Petit, E. Wirquin, K.H. Khayat, Effect of temperature on the rheology of flowable mortars, Cem. Concr. Compos. 32 (2010) 43-53. https://doi.org/10.1016/j.cemconcomp.2009.10.003.

[23] J.J. Chen, B.H. Li, P.L. Ng, A.K.H. Kwan, Adding granite polishing waste as sand replacement to improve packing density, rheology, strength and impermeability of mortar, Powder Technol. 364 (2020) 404-415. https://doi.org/10.1016/j.powtec.2020.02.012.

[24] D. Youness, A. Mechaymech, R. Al Wardany, Flow assessment and development towards sustainable self-consolidating concrete using blended basalt and limestone-cement systems, J. Clean. Prod. (2020) 124582. https://doi.org/10.1016/j.jclepro.2020.124582.

[25] Z. Zhang, J. Xiao, K. Han, J. Wang, X. Hu, Study on the structural buildup of cement-ground limestone pastes and its micro-mechanism, Constr. Build. Mater. 263 (2020) 120656.

https://doi.org/10.1016/j.conbuildmat.2020.120656.

[26] D. Jiao, C. Shi, Q. Yuan, Time-dependent rheological behavior of cementitious paste under continuous shear mixing, Constr. Build. Mater. 226 (2019) 591-600. https://doi.org/10.1016/j.conbuildmat.2019.07.316.

[27] S. Safiddine, F. Debieb, E.H. Kadri, B. Menadi, H. Soualhi, Effect of Crushed Sand and Limestone Crushed Sand Dust on the Rheology of Cement Mortar, Appl. Rheol. 27 (2017) 1-9. https://doi.org/10.3933/APPLRHEOL-27-14490.

[28] H. Soualhi, E.H. Kadri, A. Bouvet, T.T. Ngo, F. Cussigh, A.S.E. Belaidi, New model to estimate plastic viscosity of eco-friendly and conventional concrete, Constr. Build. Mater. 135 (2017) 323-334. https://doi.org/10.1016/j.conbuildmat.2017.01.009.

[29] R. Saleh Ahari, T. Kemal Erdem, K. Ramyar, Effect of various supplementary cementitious materials on rheological properties of selfconsolidating concrete, Constr. Build. Mater. 75 (2015) 89-98. https://doi.org/10.1016/j.conbuildmat.2014.11.014.

[30] H. Soualhi, E.H. Kadri, T.T. Ngo, A. Bouvet, F. Cussigh, B. Benabed, Rheology of ordinary and low-impact environmental concretes, J. Adhes. Sci. Technol. 29 (2015) 2160-2175. https://doi.org/10.1080/01694243.2015.1059641.

[31] M. Sonebi, M. Lachemi, K.M.A. Hossain, Optimisation of rheological parameters and mechanical properties of superplasticised cement grouts containing metakaolin and viscosity modifying admixture, Constr. Build. Mater. 38 (2013) 126-138. https://doi.org/10.1016/j.conbuildmat.2012.07.102.

[32] Y. Ouldkhaoua, B. Benabed, R. Abousnina, H. El-Kadri, Rheological properties of blended metakaolin self-compacting concrete containing recycled CRT funnel glass aggregate, Epa. - J. Silic. Based Compos. Mater. 71 (2019) 154-161. https://doi.org/10.14382/epitoanyag-jsbcm.2019.27.

[33] C. Özel, K.T. Yücel, Effect of Cement Content, Fibers, Chemical Admixtures and Aggregate Shape on Rheological Parameters of Pumping Concrete, Arab. J. Sci. Eng. 38 (2013) 1059-1074. https://doi.org/10.1007/s13369-012-0345-8.

[34] H. Jiang, M. Fall, E. Yilmaz, Y. Li, L. Yang, Effect of mineral admixtures on flow properties of fresh cemented paste backfill: Assessment of time dependency and thixotropy, Powder Technol. 372 (2020) 258-266. https://doi.org/10.1016/j.powtec.2020.06.009.

[35] Z. Giergiczny, Fly ash and slag, Cem. Concr. Res. 124 (2019). https://doi.org/10.1016/j.cemconres.2019.105826. 
[36] D. Jiao, C. Shi, Q. Yuan, X. An, Y. Liu, H. Li, Effect of constituents on rheological properties of fresh concrete-A review, Cem. Concr. Compos. 83 (2017) 146-159. https://doi.org/10.1016/j.cemconcomp.2017.07.016.

[37] M. Nehdi, Why some carbonate fillers cause rapid increases of viscosity in dispersed cement-based materials, Cem. Concr. Res. 30 (2000) 16631669. https://doi.org/10.1016/S0008-8846(00)00353-7.

[38] B. Felekoğlu, K. Tosun, B. Baradan, A. Altun, B. Uyulgan, The effect of fly ash and limestone fillers on the viscosity and compressive strength of self-compacting repair mortars, Cem. Concr. Res. 36 (2006) 1719-1726. https://doi.org/https://doi.org/10.1016/j.cemconres.2006.04.002.

[39] B. Felekoglu, Utilisation of high volumes of limestone quarry wastes in concrete industry (self-compacting concrete case), Resour. Conserv. Recycl. 51 (2007) 770-791. https://doi.org/10.1016/j.resconrec.2006.12.004.

[40] P. Hawkins, P. Tennis, R. Detwiler, The Use of Limestone in Portland Cement : A State-of-the-Art Review, n.d.

[41]B. Łaźniewska-Piekarczyk, The influence of selected new generation admixtures on the workability, air-voids parameters and frost-resistance of self compacting concrete, Constr. Build. Mater. 31 (2012) 310-319. https://doi.org/10.1016/j.conbuildmat.2011.12.107.

[42] D. Leonavičius, I. Pundienè, J. Pranckevičiene, M. Kligys, Selection of superplasticisers for improving the rheological and mechanical properties of cement paste with CNTs, Constr. Build. Mater. 253 (2020) 119182. https://doi.org/10.1016/j.conbuildmat.2020.119182.

[43] European Standard EN 1097-6:2000, Tests for mechanical and physical properties of aggregates - Part 6: Determination of particle density and water absorption, Brussels Eur. Comm. Stand. (2000).

[44] European Standard EN 196-1:2005, Methods of testing cement - Part 1: Determination of strength, Brussels Eur. Comm. Stand. (2005).

[45] European Standard EN 12350-2:2009, Testing fresh concrete Slump-test, Brussels Eur. Comm. Stand. (2009).
[46] H. Soualhi, E.H. Kadri, T.T. Ngo, A. Bouvet, F. Cussigh, S. Kenai, A vane rheometer for fresh mortar: Development and validation, Appl. Rheol. 24 (2014) 1-7. https://doi.org/10.3933/ApplRheol-24-22594.

[47] J. Jeong, E. Chuta, H. Ramézani, S. Guillot, Rheological properties for fresh cement paste from colloidal suspension to the three-element KelvinVoigt model, Rheol. Acta. 59 (2020) 47-61. https://doi.org/10.1007/s00397-019-01171-x.

[48] T. Sedran, F. De Larrard, L. Le Guen, Determination of the compaction of cements and mineral admixtures using the vicat needle, Bull. Des Lab. Des Ponts Chaussees. (2007) 155-163.

[49] E.P. Koehler, D.W. Fowler, Development of a Portable Rheometer for Fresh Portland Cement Concrete, ICAR REP. (2004) 103-105.

[50] N. Roussel, Understanding the Rheology of Concrete, Woodhead Publishing, 2012. https://doi.org/10.1533/9780857095282.index.

[51] O.H. Wallevik, J.E. Wallevik, Rheology as a tool in concrete science: The use of rheographs and workability boxes, Cem. Concr. Res. 41 (2011) 1279-1288. https://doi.org/10.1016/j.cemconres.2011.01.009.

[52] M. Criado, A. Palomo, A. Fernández-Jiménez, P.F.G. Banfill, Alkali activated fly ash: Effect of admixtures on paste rheology, Rheol. Acta. 48 (2009) 447-455. https://doi.org/10.1007/s00397-008-0345-5.

Ref.:

Safiddine, Salim - Soualhi, Hamza - Benabed, Benchaa - Belaidi, Akram Salah Eddine - Kadri, El-Hadj: Effect of different supplementary cementitious materials and superplasticizers on rheological behavior of eco-friendly mortars

Építőanyag - Journal of Silicate Based and Composite Materials, Vol. 73, No. 3 (2021), 119-129. p. https://doi.org/10.14382/epitoanyag-jsbcm.2021.18
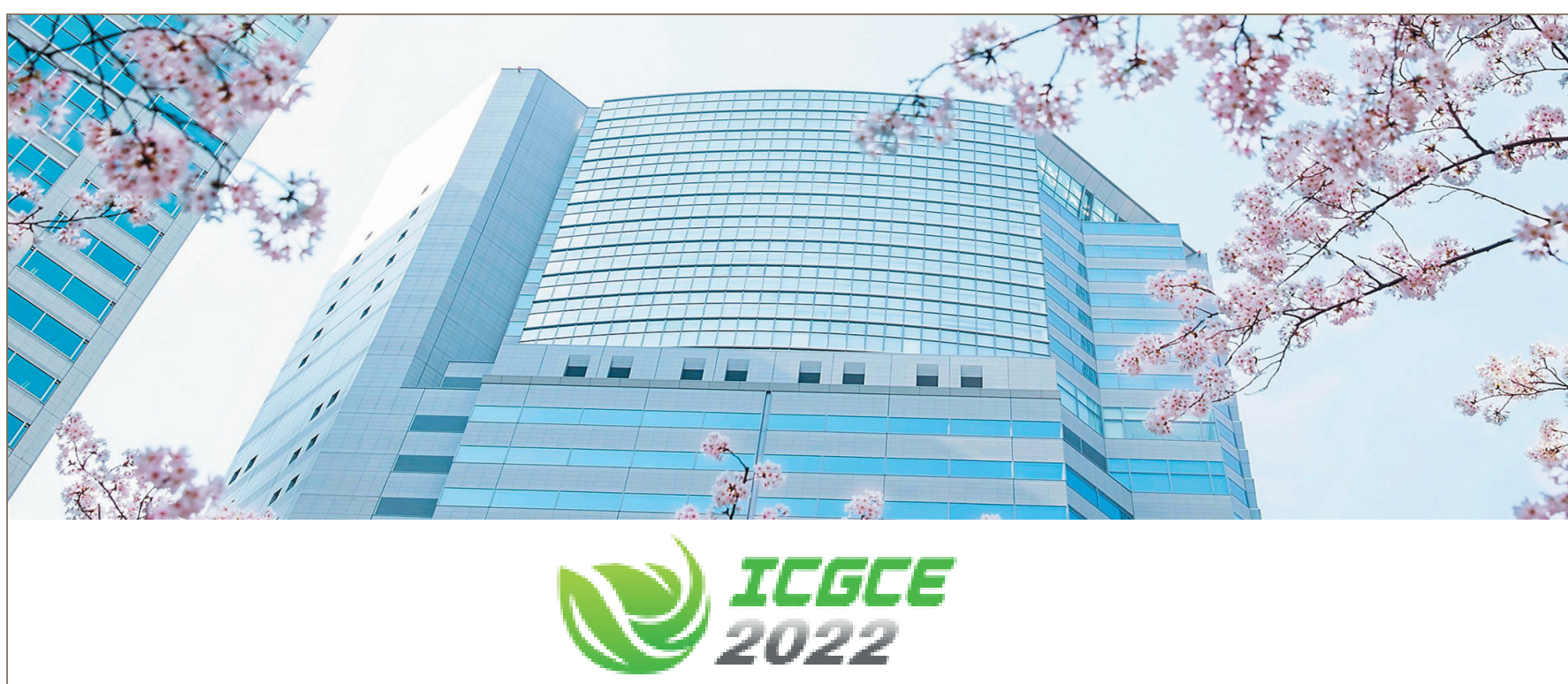

\section{$20229^{\text {TH }}$ INTERNATIONAL CONFERENCE ON GEOLOGICAL AND CIVIL ENGINEERING TOKYO, JAPAN, JANUARY 20-22, 2022}

The aim of the 2022 9th International Conference on Geological and Civil Engineering (ICGCE 2022) is to provide a platform for researchers, engineers, academicians as well as industrial professionals from all over the world to present their research results and development activities in Geological and Civil Engineering.

ICGCE 2022 provides opportunities for the delegates to exchange new ideas and application experiences face to face, to establish business or research relations and to find global partners for future collaboration.

www.icgce.org• icgce@cbees.net 